\title{
Histomorphometrical Analysis of Coronary Atherosclerosis Lesions Formation in Rat (Rattus norvegicus) Model
}

\author{
Rheza Permana ${ }^{1}$, Fatkhur Rizqi ${ }^{1}$, Ardian Pradana ${ }^{1}$, I Dewa A. Susilawati², Tantin Ermawati² \\ ${ }^{1}$ Undergraduate Program, Faculty of Dentistry, University of Jember, Jember 68121, Indonesia \\ ${ }^{2}$ Faculty of Dentistry, University of Jember, Jember 68121, Indonesia \\ Corresponding e-mail: rhezapermana90@gmail.com
}

\begin{abstract}
Cardiovascular disease is the most deadly disease in the world and the main cause is atherosclerosis. New paradigm explains that chronic inflammation such as periodontitis is considered to be a risk factor for atherosclerosis. Periodontitis causes bacteremia affecting vascular inflammation. This situation affects the endothelial cells and lipid oxidation thereby increasing the risk of atherosclerosis. This study aimed to prove the effect of periodontitis on coronary atherosclerotic lesion formation. Methods: This was an experimental study using the post-test only control group design. Samples were 12 rats divided into control group $(\mathrm{K})$ without treatment and periodontitis $(\mathrm{P})$ was made with the installation of wire ligature and injection of Porphyromonas gingivalis on the left mandibular M1 for 28 days. On day 29, mice were decaputated, coronary artery was taken and histological slides were made. Histomorphometrical analysis was calculated on dungkul (descriptive) and the thickness of the arterial wall (with test statistic $\mathrm{T}$ test). Results: The results showed higher formation of arterial dungkul on Periodontitis group $(83.33 \%)$ than the control group $(16.67 \%)$. Arterial wall was also thicker periodontitis group $(2.22 \pm 0.35 \mu \mathrm{m})$ $(p<0.05)$ than the control group $(1.28 \pm 0.20 \mu \mathrm{m})$. Conclusion: Periodontitis can independently affect the coronary atherosclerotic lesion formation.
\end{abstract}

\begin{abstract}
ABSTRAK
Analisis histomorfometrik pembentukan lesi aterosklerosis koroner pada model tikus (Rattus novergicus) periodontitis. Penyakit kardiovaskuler perupakan penyakit paling mematikan di dunia dan penyebab utamanya adalah aterosklerosis. Paradigma baru menjelaskan bahwa inflamasi kronis seperti periodontitis dipertimbangkan sebagai faktor risiko terjadinya aterosklerosis. Periodontitis menyebabkan bakteremia yang berpengaruh terhadap inflamasi vaskuler. Keadaan ini mempengaruhi sel endotel dan oksidasi lipid sehingga meningkatkan resiko aterosklerosis. Tujuan: Penelitian ini bertujuan untuk membuktikan pengaruh periodontitis terhadap pembentukan lesi aterosklerosis koroner. Metode: Penelitian ini merupakan eksperimen menggunakan the post test only control group design. 12 sampel tikus dibagi atas kelompok kontrol (K) tanpa perlakuan dan kelompok periodontitis (P) dibuat dengan pemasangan wire ligature dan injeksi Porphyromonas gingivalis pada M1 rahang bawah kiri selama 28 hari. Pada hari ke-29 tikus didekaputasi, arteri koroner diambil dan dibuat preparat histologi. Analisis histomorfomerik dilakukan pada morfologi dungkul (deskriptif) dan ketebalan dinding arteri (statistik dengan uji T test). Hasil: Hasil penelitian menunjukkan bahwa terbentuknya dungkul arteri lebih banyak pada kelompok Periodontitis (83,33\%) daripada kelompok Kontrol (16,67\%). Dinding arteri kelompok periodontitis juga lebih tebal $(2,22 \pm 0,35 \mu \mathrm{m})$ secara signifikan dibandingkan kelompok kontrol $(1,28 \pm 0,20 \mu \mathrm{m})(p<0,05)$. Simpulan: Periodontitis secara independen dapat mempengaruhi gambaran histomorfometrik pembentukan lesi aterosklerosis koroner.
\end{abstract}

Keywords: coronary atherosclerosis, Porphyromonas gingivalis, rat model periodontitis 


\section{PENDAHULUAN}

Data statistik WHO tahun 1995 menunjukkan bahwa penyakit kardiovaskuler menjadi penyakit yang paling mematikan di dunia. Di negara maju, 50\% kematian disebabkan oleh penyakit kardiovaskuler, sedangkan di negara-negara berkembang nilainya lebih kecil yaitu sekitar $16 \% .{ }^{1}$ Penyakit ini menyebabkan kegagalan jantung dalam memompa darah sehingga suplai darah terhenti. Pencetus utama penyakit ini adalah aterosklerosis. ${ }^{2}$

Aterosklerosis merupakan penyakit vaskuler yang ditandai dengan penebalan dinding arteri yang membentuk unit lesi, atau ateroma (dungkul arteri). Lesi aterosklerosis terdiri dari lemak dilapisi jaringan ikat fibrosa (fibrous cap). Timbulnya plak ateroma ini dapat menyebabkan penyempitan lumen arteri, dan apabila plak ateroma pecah, akan menimbulkan trombosis dan gangguan aliran darah. ${ }^{3}$ Gangguan aliran darah ini dapat menyebabkan terjadinya iskemia dan kematian jaringan di daerah seperti pada jantung dan otak. Apabila terjadi pada arteri koroner, hal ini menimbulkan gangguan jantung ditandai nyeri dada (angina pectoris) dan kematian otot jantung (myocardial infarction). ${ }^{4}$ Keadaan ini sering berakibat fatal dan dapat menyebabkan kematian. ${ }^{3}$

Beberapa tahun terakhir terjadi pergeseran konsep patogenesis aterosklerosis bahwa lemak yang abnormal bukan lagi menjadi etiologi utama penyakit aterosklerosis, tetapi infeksi diyakini sebagai stimulus inflamasi penting yang menyebabkan aterosklerosis. Proses inflamasi dapat terjadi secara langsung atau tidak langsung melibatkan pembuluh darah melalui hemostatik dan pemicu inflamasi sistemik. Bakteri dan produknya dapat merusak pembuluh darah secara langsung dengan mempengaruhi metabolisme lemak, koagulasi darah, monosit, makrofag atau sel endotel. Perubahan ini dapat menyebabkan peningkatan resiko terjadinya aterosklerosis. Salah satu bakteri yang diduga berpengaruh pada pembentukan aterosklerosis adalah bakteri periodontitis. ${ }^{5}$

Periodontitis merupakan penyakit yang umum diderita manusia. Periodontitis adalah penyakit keradangan pada jaringan pendukung gigi yang disebabkan oleh kelompok mikroorganisme terutama bakteri batang gram negatif, Bacteroides forsythus dan Porphyromonas gingivalis. Kerusakan jaringan periodontal dapat menyebabkan bakteri masuk ke dalam sirkulasi darah melalui gusi yang berdarah. ${ }^{6}$ Bakteri yang masuk ke dalam sirkulasi darah ini dapat mengakibatkan aterosklerosis bahkan infark miokardial akut (IMA). ${ }^{7}$

Menurut Wijayanti dan Setyopranoto terdapat hubungan antara periodontitis dengan ateroskeloris. ${ }^{8}$ Terdapat beberapa kemungkinan yang dapat menjelaskan hubungan keduanya, yaitu adanya kemungkinan sebagai faktor yang bersamaan timbulnya, misalnya merokok, obesitas, dan diabetes, menggambarkan suatu kecenderungan yang bersifat individual berupa perkembangan respon inflamasi secara cepat yang dipengaruhi faktor intrinsik (umur, kelamin, gen) dan pengaruh ekstrinsik (diet, lingkungan dan lain-lain), yang selanjutnya sebagai predisposisi terjadinya penyakit periodontal maupun aterosklerotik.

Infeksi bakteri periodontal mampu merangsang pelepasan sitokin, seperti tumor nekrosis faktor- $\alpha$ (TNF- $\alpha$ ), interleukin (IL-1 $\beta$, IL-6, dan IL-8). Satu dari stimuli potensial ini adalah lipopolisakarida (LPS) endotoksin, hadir dalam plak subgingiva dengan periodontitis yang parah. LPS mampu meningkatkan ambilan low density lipoprotein (LDL) oleh monosit sehingga terbentuk sel busa (foam cell), yang merupakan komponen kunci dari aterosklerosis. $^{9}$

Penelitian juga menunjukan bahwa bakterimia $P$. gingivalis dapat menginduksi pembentukan lesi aterosklerosis. Lesi aterosklerosis ini hanya dapat dideteksi melalui pemeriksaan histopatologi. Sejauh ini, penelitian eksperimental tentang pengaruh periodontitis pada pembentukan lesi aterosklerosis belum banyak dilakukan.

\section{METODE}

Bahan yang digunakan untuk pembuatan tikus periodontitis adalah tikus wistar jantan (Rattus norvegicus), wire ligature diameter $0,5 \mathrm{~mm}$, Porphyromonas gingivalis tipe ATCC 33277 dengan dosis $5 \mu \mathrm{g} / 0,05 \mathrm{~mL}$ PBS, ketamin (KTM 1000) dengan dosis $80 \mathrm{mg} / \mathrm{kg}$ ditambah akuades steril. pakan yang digunakan adalah pelet jenis B76.

Bahan yang digunakan untuk prosesing jaringan terdiri atas formalin 10\%, ammonium hydroxide 5\%, ammonium oxalate 5\%, alkohol konsentrasi bertingkat mulai $70 \%, 80 \%, 95 \%$, dan $100 \%$, embedding paraffin (Paraplast Plus), xylol, haematoksilin eosin (HE), oil red, dan entellan. 
Penelitian eksperimental ini menggunakan rancangan the post test only control group design. Objek penelitian adalah 12 ekor tikus wistar jantan, dengan kriteria tikus umur 3-4 bulan dan dalam keadaan sehat. Tikus dibagi dalam dua kelompok yaitu kelompok kontrol $(\mathrm{K})$ dan kelompok perlakuan $(\mathrm{P})$. Kelompok $\mathrm{K}$ tidak diberi perlakuan, hanya diberi pakan standart. Kelompok P menggunakan model tikus periodontitis yaitu tikus yang dipasangkan wire ligature dan injeksi $P$. gingivalis pada gigi molar pertama rahang bawah kiri tiga kali dalam seminggu selama empat minggu. konsentrasi $P$. gingivalis yang digunakan adalah $5 \mu \mathrm{g} / 0,05 \mathrm{~mL}$ PBS. Tikus diberi makan setiap harinya dengan pakan standar.

Penelitian dimulai dari tahap adaptasi tikus dan persiapan bahan. Pemasangan wire ligature pada gigi molar pertama rahang bawah kiri dan dilakukan pada hari pertama sebelum injeksi $P$. gingivalis. Sebelumnya dilakukan pembiusan secara intramuskular dengan ketamin (KTM 1000) dengan dosis $80 \mathrm{mg}$ / $\mathrm{kg}$ atau senilai $0,02 \mathrm{~mL}$. Setelah pemasangan selesai, dilakukan injeksi $P$. gingivalis dengan konsentrasi $5 \mu \mathrm{g} / 0,05 \mathrm{~mL}$ sebanyak $0,02 \mathrm{~mL}$ pada bukal gigi molar pertama rahang bawah kiri dan diberikan seminggu tiga kali selama empat minggu. Pada hari ke-29, seluruh sampel dilakukan dekaputasi dan dilanjutkan dengan pengambilan jaringan arteri koroner yang kemudian difiksasi dengan formalin 10\%. Kemudian dilakukan processing jaringan yang berfungsi untuk mempersiapakan jaringan sebelum dipotong.

Processing jaringan dimulai dengan dehidrasi dengan menggunakan alkohol konsentrasi bertingkat $70 \%$, 80\%, 95\%, dan 100\%, clearing dengan xylol, Impregnasi, dan embedding dengan parafin pada suhu $56-58^{\circ} \mathrm{C}$. Selanjutnya dilakukan pemotongan jaringan dengan mikrotom secara melintang. Hasil dari pemotongan dicat dengan HE dan didapatkan preparat jaringan yang siap untuk diamati. Tahap pengamatan dilakukan dibawah mikroskop dengan perbesaran 400x untuk melihat terbentuknya dungkul. Pengukuran ketebalan dinding dilakukan menggunakan alat mikrometer grade. Setelah mendapatkan hasil dilakukan analisis data menggunakan uji $T$ test.

\section{HASIL}

Hasil penelitian menunjukkan bahwa pada kelompok P (tikus periodontitis) lebih banyak terbentuk dungkul $(83,33 \%)$ daripada kelompok kontrol $(16,67 \%)$. Data morfologi ada tidaknya dungkul tersaji pada Tabel 1 .
Secara histologi, perbedaan gambaran morfologi arteri kelompok kontrol dan kelompok perlakuan terlihat pada Gambar 2 dan Gambar 3. Setelah dilakukan perbandingan ukuran ketebalan dinding arteri koroner antara kedua kelompok, didapatkan bahwa kelompok perlakuan mempunyai dinding arteri yang lebih tebal dibanding kelompok kontrol. Nilai rerata ketebalan dungkul arteri pada kelompok kontrol adalah $1,28 \pm 0,20 \mu \mathrm{m}$, sedangkan kelompok perlakuan adalah $2,22 \pm 0,35 \mu \mathrm{m}$ (Gambar 4). Hasil pengukuran ketebalan dinding arteri kononer dilakukan $t$-Test menunjukan nilai signifikansi adalah $0,00(p<0,005)$. Hal ini menunjukan bahwa adanya perbedaan yang signifikan antara kelompok kontrol dan kelompok perlakuan.

Tabel 1. Jumlah dungkul arteri koroner yang terbentuk pada hewan coba

\begin{tabular}{lccc}
\hline & N & $\begin{array}{c}\text { Jumlah dungkul } \\
\text { arteri }\end{array}$ & Persentase \\
\hline Kontrol & 18 & 3 & $16,67 \%$ \\
Perlakuan & 18 & 15 & $83,33 \%$ \\
\hline
\end{tabular}

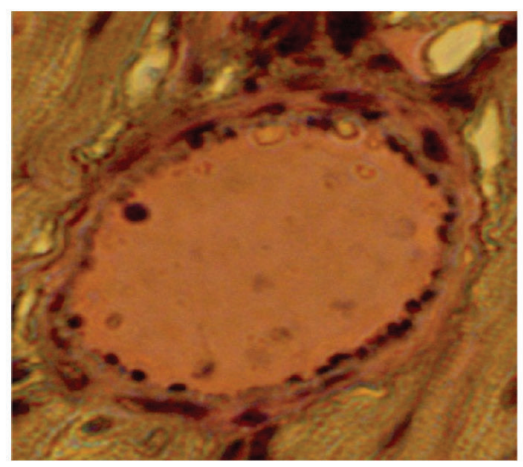

Gambar 2. Arteri koroner kelompok kontrol, tidak periodontitis. Terlihat bentukan arteri tampak dinding arteri berbentuk bulat, permukaan rata dan tidak ada tonjolan atau penebalan dinding

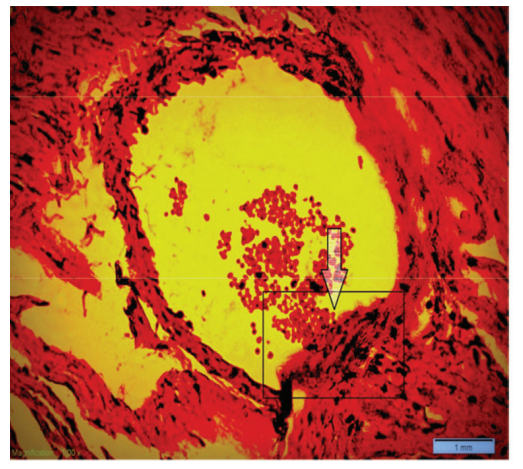

Gambar 3. Arteri yang mengalami aterosklerosis pada tikus periodontitis. Bentukan arteri tidak teratur, ketebalan dinding tidak rata dan ada tonjolan/penebalan dinding, daerah yang ditandai adalah daerah terbentuknya dungkul yang mengalami penebalan (area di dalam kotak) 


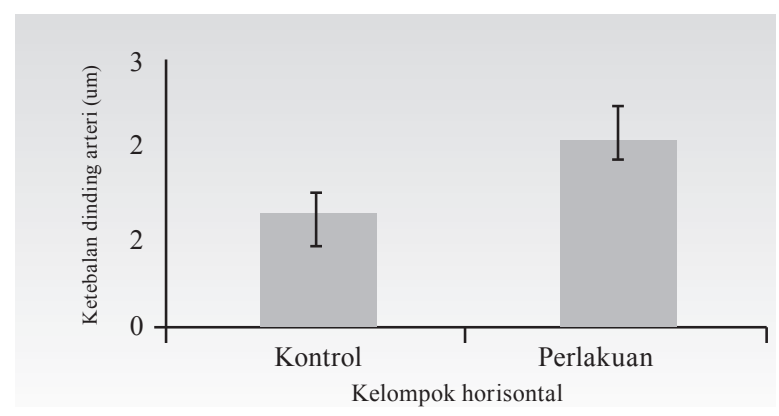

Gambar 4. Diagram rerata ketebalan dinding arteri antara kelompok kontrol dan perlakukan. Kelompok P mempunyai ketebalan dinding dungkul arteri yang hampir dua kali lebih banyak dari kelompok K. $(t-T e s t ; p<0,005)$

\section{DISKUSI}

Penelitian ini bertujuan untuk membuktikan pengaruh periodontitis terhadap pembentukan lesi aterosklerosis koroner. Hasil penelitian ini memperlihatkan bahwa periodontitis mempengaruhi morfologi arteri koroner. Tikus dengan periodontitis lebih banyak ditemukan lesi arterosklerosis, yaitu 83,33\% daripada kelompok kontrol 16,67\%.

Hasil lain menunjukan bahwa ketebalan dinding arteri koroner kelompok dengan periodontitis juga lebih tebal yaitu rata-rata $2,22 \mu \mathrm{m}$, ketebalan minimal $1,72 \mu \mathrm{m}$ dan ketebalan maximal $2,83 \mu \mathrm{m}$. Sedangkan Kelompok kontrol ketebalan rata-rata $1,28 \mu \mathrm{m}$, ketebalan minimal $1,08 \mu \mathrm{m}$ dan ketebalan maximal $1,50 \mu \mathrm{m}$. Hal ini membuktikan bahwa adanya pengaruh periodontitis terhadap ketebalan dinding arteri koroner.

Periodontitis menyebabkan sel-sel bakteri atau produknya seperti lipopolisakarida (LPS), fragmen peptidoglikan, enzim-enzim hidrolitik, dapat masuk ke sirkulasi darah (bakteremia). Terdapatnya bakteri dan produk-produknya di dalam sirkulasi darah, menimbulkan respon sistemik, berupa peningkatan antibodi $\mathrm{IgG}$ dan peningkatan beberapa marker inflamasi sistemik dalam serum darah penderita periodontitis seperti CRP, IL-6, dan sejumlah netrofil. ${ }^{11-13}$ Dilaporkan bahwa $P$. gingivalis dapat memproduksi sitokin pro-inflamatori dalam jumlah besar, seperti IL-1, IL-6, IL-8 dan tumor nekrosis faktor (TNF)- $\alpha$ pada darah yang dapat menyebabkan terbentuknya lesi ateroma. ${ }^{14}$

Dalam sebuah penelitian dijelaskan bahwa produk-produk bakteri akan menyebabkan infiltrasi sel-sel inflamasi ke dalam dinding arteri, proliferasi otot polos arteri dan koagulasi intravaskuler. ${ }^{16}$ Periodontitis menyebabkan infeksi sistemik kronis, keadaan bakterimia mengawali respon tubuh dengan mempengaruhi koagulasi, endotel, dan fungsi platelet, menyebabkan ateroma dan terjadinya tromboemboli. ${ }^{16}$

Infeksi periodontal berpotensi menjadi infeksi sistemik, ini menyebabkan keadaan hiperkoagulasi dan peningka- tan viskositas darah. Pasien dengan penyakit periodontal sering kali mengalami peningkatan fibrinogen dan sel darah putih. Individu dengan kesehatan mulut yang buruk secara signifikan terjadi peningkatan faktor koagulasi VIII Vob Willebrand Factor, hal ini dapat meningkatkan viskositas darah dan trombogenesis, keadaan ini meningkatkan resiko penyakit vascular., 15

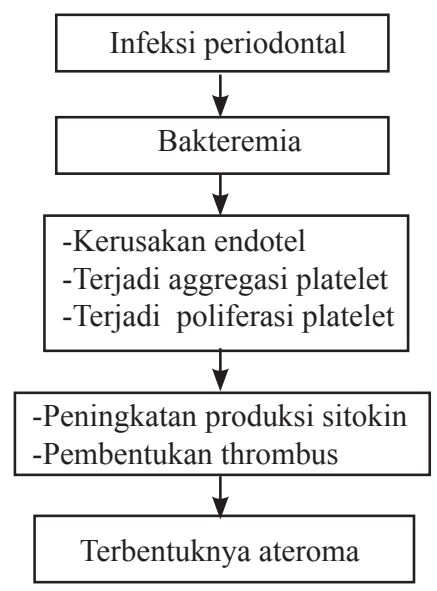

Gambar 5. Diagram pengaruh infeksi periodontal pada aterosklerosis. Bakteri dan produknya merusak endotel, monosit masuk ke dinding pembuluh darah, sitokin meningkatkan terjadinya lesi aterosklerosis ${ }^{16}$

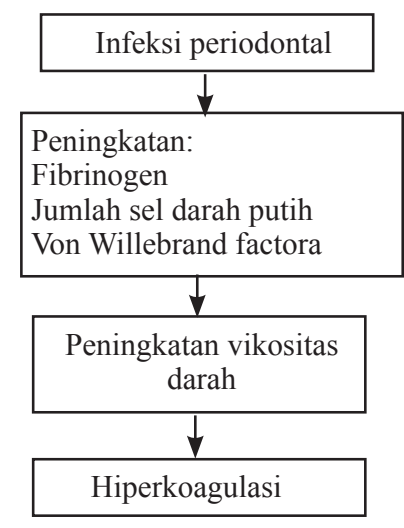

Gambar 6. Diagram pengaruh infeksi pada viskositas darah, peningkatan plasma fibrinogen dan von Willebrand factor menyebabkan hiperkoagulasi ${ }^{9,15}$

Pembentukan plak ateroma menyebabkan penebalan dinding pembuluh darah akibat terjadi penyempitan lumen arteri dan berkurangnya aliran darah. Trombosis sering terjadi setelah pecahnya plak ateroma, terjadi pengaktifan platelet dan jalur koagulasi. kumpulan platelet dan fibrin dapat menutupi pembuluh darah., ${ }^{916}$

Penyakit aterosklerosis dan periodontitis merupakan suatu keadaan inflamasi yang umum dijumpai pada manusia. Di dalam proses aterogenesis, proses inflamasi terjadi secara terus menerus yang berperan terhadap munculnya sel endotel, pembentukan plak, sampai pecahnya plak pada pembuluh darah. Munculnya infeksi seperti periodontitis menguatkan inflamasi dalam ateroskerosis. Studi observasi terkini terus memperlihatkan adanya peningkatan 
resiko yang cukup signifikan untuk terjadinya penyakit aterosklerosis pada individu dengan penyakit periodontal. ${ }^{15}$ Hasil penelitian ini dapat menjadi dasar perlunya penelitian lebih lanjut yang membandingkan periodontitis dan faktor lain terhadap pembentukan aterosklerosis koroner.

\section{SIMPULAN}

Periodontitis mempengaruhi pembentukan lesi aterosklerosis koroner dan menebabkan penebalan dinding arteri koroner pada model tikus periodontitis.

\section{DAFTAR PUSTAKA}

1. Beck JD, Slade G, Effenbacher S. Oral disease, cardiovascular disease and systemic inflammation. Periodontol. 2004;23:110-19

2. Ross R. Aterosclerosis and inflammatory disease. N Engl J Med. 1999;340:115-26.

3. Suryohudoyo P. Kapita selekta ilmu kedokteran molekuler. Jakarta: CV Sagung Seto; 2002 Indonesian.

4. Price SA, Wilson LM. Pathophysiology: clinical concepts of disease process. 6th ed. St. Louis:Mosby; 2003.

5. Agus S, Yanti R. Penyakit periodontal dan penyakit jantung koroner (aterosklerosis). Bandung: UNPAD; 2010. Indonesian.

6. Caranza FA Jr. In: Glickman's Clinical Periodontology. 6th ed. Philadelphia London: WB Saunders Co.; 2006.

7. Manson JD, Eley BM. Periodontics. 5th ed. Edinburgh London: Elsevier; 2004.
8. Wijayanti PM, Setyopranoto I. Hubungan antara periodontitis, aterosklerosis dan stroke iskemik akut. Yogyakarta : Departemen Ilmu Kesehatan Masyarakat Fakultas Kedokteran Universitas Islam Indonesia; 2008. Indonesian

9. Mealey BL, Perry RK. Periodontal Medicine : Impact of periodontal infection on systemic health. Philadelphia: WB Saunder Company; 2006.

10. Li X, Koltveit KM, Tronstad L, Olsen I. Systemic disease caused by oral infection. Clin Microbiol Rev. 2010; 13:547-58.

11. Kurihara H, Nishimura F, Nakamura T, Nakagawa M, Tanimoto I, Nomura Y, et al. Humoral immune response to an antigen from Porphyromonas gingivalis 381 in periodontal disease. Infect Immun. 1991;59:2758-62.

12. Ogawa T, Ucida, Hamada S. Porphyromonas gingivalis fimbriae and their synthetic peptides induce proinflamatory cytokines in human peripherial blood monocyte cultures. FEMS Microbiol Lett. 2004;116:237-42.

13. D’ Auito F, Parkar M, Andreou G, Suvan J, Brett, Ready D, Tonetti MS. Periodontitis and systemic inflammation: control of local infection is associated with a reduction in serum inflammatory marker. $\mathrm{J}$ Dent Res. 2004;83:156-60.

14. Loos BG, Craandijk J, Hoek FJ, van Dillen W. Elevation of systemic marker related to cardiovascular disease in the peripheral blood of periodontitis patients. J Periodontol. 2000:71;1528-34.

15. Paquette DW, Brodala N, Nichols TC. Cardiovascular disease, inflammation, and periodontal infection. Periodontol 2000. 2007;44:113-26.

16. Varma BRR, Nayak RP. Current concepts in periodontics. 1st ed. New Delhi: Chaman Enterprises; 2002. 